\title{
New species in Orchidaceae from Madagascar
}

\author{
Johan Hermans $^{1,2}$ (D), Landy Rajaovelona ${ }^{3}$ \& Phillip Cribb ${ }^{1}$
}

Summary. Five new species from Madagascar, Aerangis bovicornu (Vandeae: Angraecinae), Angraecopsis lemurelloides (Vandeae: Angraecinae), Didymoplexis stella-silvae (Gastrodieae), Habenaria crocodilium (Orchideae: Orchidinae) and Polystachya siederi (Vandeae: Polystachinae) are described and illustrated. A short summary of endemism and the history of description of orchids of Madagascar are given.

Key Words. Distribution, endemism, history, IUCN Red List assessments, new species, taxonomy.

\section{Introduction}

The flora and fauna of Madagascar are well known for their exceptionally high levels of diversity and endemism ( $85 \%$ of its species), the island having also been identified as one of the most important biodiversity hotspots (Myers et al. 2000: 855). The Orchidaceae are the largest plant family on Madagascar (Callmander et al. 2011: 122) and novelties are still discovered frequently. A new tabulation by one of the authors $(\mathrm{JH})$ of all orchids currently recognised (April 2019) from Madagascar and surrounding W Indian Ocean Islands shows that there are now a total of 1002 species, subspecies (17) and varieties (51) known from Madagascar. Eighty-five percent of these are endemic to Madagascar and this endemism increases to c. $95 \%$ when the surrounding archipelagos of the Mascarenes, Comoros and the Seychelles are included.

Many botanists and collectors have been involved in the discovery of this remarkable orchid flora but only a few are responsible for their formal description. Until the 1820's, only a handful of orchid species were recognised from Madagascar and most were then only known from the Mascarene Islands. In 1822, Louis Marie Aubert du Petit Thouars described and illustrated 31 species from the island (Thouars 1822). Between 1824 and 1850, John Lindley added another 15 species. Heinrich G. Reichenbach $f$. described a further 51 between 1850 and 1885, mostly based on collections by Johann Hildebrandt (Reichenbach 1881a \& b) and Léon Humblot (Reichenbach 1885a \& b). Between 1883 and 1886, Henry Ridley described 57 new species based on collections by various missionaries, mainly of the London Missionary Society, including William Deans Cowan (Ridley 1883), Richard Baron and Joseph Tregelles Fox (Ridley 1885, 1886). Robert A. Rolfe added 23 species in the 1890's from a variety of sources but principally from commercial collectors. Rudolf Schlechter contributed no fewer than 282 new names to the list between 1911 and 1925 with most of them based on collections by the French explorer Henri Perrier de la Bâthie (Schlechter 1913, 1915, 1916, 1918a \& b, 1922, 1924, 1925 and 1932 posthumously). Following Schlechter's death in 1925, Perrier de la Bâthie described many novelties (Perrier 1930, 1934, 1936a, b, c, 1937, 1938a, b, c, d, 1939a, 1951, 1955) and revised a number of genera. Perrier's work culminated in the orchid volumes of the Flore de Madagascar (Perrier in Humbert 1939b \& 1941). He described 195 novelties mainly based on his own collections but also those of Raymond Decary, Henri Humbert and others working on the island during the French colonial era between 1929 and 1955. From the early 1960s until 2013, Jean Bosser, in collaboration with others, described 102 new taxa (Bosser 1965, 1969a, b, c, d, 1970a, b, 1971, 1980, 1989, 2000) and published an illustrated orchid flora of the Island with Marcel Lecoufle in 2011 (Bosser \& Lecoufle 2011). Recent work by Johan Hermans, Phillip Cribb and collaborators has added 57 new orchids to the flora (most notably Hermans et al. 2007, 2017; Hermans \& Cribb 2014 \& others in press) together with a new checklist, bibliography (Hermans et al. 2007) and Field Guide (Cribb \& Hermans 2009). The most recent illustrated guide is by Hervouet (2018).

As part of ongoing research and fieldwork on the orchid flora of Madagascar at the Royal Botanic Gardens Kew, the University of Vienna and PBZT Antananarivo, specimens of putative new taxa were compared with descriptions, herbarium material and drawings of all the type specimens of the genus to ascertain their novelty. This has resulted in the recognition of a number of new species.

\footnotetext{
Accepted for publication 28 February 2020. Published online 15 March 2021

1 Herbarium, Royal Botanic Gardens, Kew, Richmond, Surrey, TW9 3AE UK. e-mail: j.hermans@kew.org

2 Core Facility, Botanical Garden, University of Vienna, Rennweg 14, 1030 Vienna, Austria.

3 Kew Madagascar Conservation Centre, Lot II J 131 Ambodivoanjo, Ivandry, Madagascar.
} 


\section{IUCN Red List assessments}

The conservation status of the new species given in this paper are summaries of the full IUCN Red List assessments which will be completed and submitted for review and publication by IUCN once the species names are validly published and therefore available for assessment. All the assessments have been compiled based on current knowledge of these taxa, by one of the authors (Landy Rajaovelona), who is an IUCN Red List assessor, using the IUCN Red List Categories and Criteria (2012).

\section{New Species}

Aerangis bovicornu Hermans sp. nov. Type: Madagascar, Fianarantsoa prov., near Ankazomivady, in lee side of large inselberg, 1797 m, Dec. 1997, Hermans 8179 (holotype K!).

http://www.ipni.org/urn:lsid:ipni.org:names:77214543-1

Short monopodial epiphytic herb up to $5 \times 6.5 \mathrm{~cm}$, with a short woody stem c. $8 \mathrm{~mm}$ in diam., covered in brown corrugate sheaths, bearing numerous somewhat hirsute orange-brown roots becoming grey with age, c. $1.5 \mathrm{~mm}$ in diam. Leaves $3-5$, leathery, on a short $3-5 \mathrm{~mm}$ conduplicate petiole, ovate to elliptic, $20-33 \times 16-22$ $\mathrm{mm}$, somewhat convex, emarginate at the tip, laevigate, more or less brownish-orange on the upper surface, greyish-green, punctate underneath with the central vein darker. Inflorescence very short, up to $2.5 \mathrm{~cm}$ long, bearing $2-3$ flowers and an aborted bud. Rachis $3-$ $5 \mathrm{~mm}$ in diam., orange-brown, almost entirely covered with $2-3$ conduplicate to almost tubular bracts, $3.4-4.8$ $\times 1.8-2.1 \mathrm{~mm}$. Floral bracts thin, amplexicaul, $1.8-2.3 \times$ $1.8 \times 2 \mathrm{~mm}$. Flowers c. $10 \times 10 \mathrm{~mm}$ without the spur, about $10 \mathrm{~mm}$ apart, stellate, not opening fully; petals, sepals and lip white with the tips sometimes tinged with orange, the ovary and spur orange-brown, the buds green. Pedicel and ovary straight, rounded, slightly ridged, $8-12 \times 1.9-$ $2.3 \mathrm{~mm}$. Dorsal sepal ovate-elliptic, acuminate, $7.8-8.6 \times$ $3.6-3.9 \mathrm{~mm}$, narrowed, reflexed towards the base. Lateral sepals obliquely lanceolate, acuminate, $8.7-8.9 \times$ $3.5-3.7 \mathrm{~mm}$. Petals ovate elliptic, obtuse, $8.3-8.6 \times 3.8-$ $4.1 \mathrm{~mm}$. Lip ovate-lanceolate, attenuate, $7.6-8.2 \times 3.9-$ $4.1 \mathrm{~mm}$; spur slender, horn-shaped, terete at the tip, a little broadened towards the base, $20-23 \times 0.9-1.3 \mathrm{~mm}$. Column short, stout, slightly winged, broadly mucronate at the apex, rostellum ligulate-ensiform, up to $5 \mathrm{~mm}$ long; anther broadly obovoid with a small rounded swelling at the apex, up to $1.4 \times 1.6 \mathrm{~mm}$; pollinia globose c. $0.8 \times 0.6 \mathrm{~mm}$, stipes short and slender, viscidium elongate, narrow. Seed capsule fusiform, glabrous, brown, $16 \times 5 \mathrm{~mm}$. Figs $1 \mathrm{~A}, \mathrm{~B} ; 2$.

RECOGNITION. Aerangis bovicornu is a few-flowered compact plant with small flowers that do not open fully, ovate to elliptic leaves which are brownishorange on top and greyish-green underneath; the stellate flowers have a short horn-shaped spur and white perianth with an orange-brown ovary and spur and long rostellum and anther with a small rounded swelling at the apex. It is undoubtedly most closely related to Aerangis fastuosa (Rchb.f.) Schltr. (Schlechter 1914: 598) (Fig. 1C) but differs substantially in its flowers which are consistently a third of the size, the straight slender, up to $23 \mathrm{~mm}$ long, spur which is consistently much shorter (vs a minimum of $76 \mathrm{~mm}$ in $A$. fastuosa), the perianth tips and spur coloured brownish-orange (vs generally white), the narrower column apex and the obovoid anther with a small rounded swelling at the apex (vs conical with a long beak). The new species flowers from December to January whilst Aerangis fastuosa flowers earlier from June to November. Table 1 shows a comparison of characteristics and measurements based on 28 herbarium specimens [Lawrence (BM00540114); Baron s.n. (K); Hillerman 12, 13, s.n. (K); Kotozafy 334 (K); Pettersson E Nilsson 380 (K); Hermans 3240, 3766, 4139, 4277, 5169, 5449, 5485, 6664, 6666 (all K); Humblot s.n. (W-R46259); Hort. (W-R30844); Hildebrandt 4207 (W); cult. Lendy (W-R29591); cult. Low (W-R28278); G. Fischer et al. FS1586-2004 (WU); Humbert E Cours 17779 (P); Bosser 14643, 16423 (P); Decary 18402 (P); Rakotoson 12418RN (P); Bernardi 11128 (P)].

DISTRIBUTION. Endemic to south-central Madagascar, Fianarantsoa province, only known from the type collection.

HABITAT. Epiphyte on small moss- and lichen-covered trees in remnants of forest on granite inselberg. Elevation c. $1800 \mathrm{~m}$.

CONSERVATION STATUS. Recent observations by one of the authors $(\mathrm{JH})$ found only six plants remaining in the type locality, one bearing an immature seed capsule. The area has now been cleared for cultivation of Pelargonium, grown increasingly in the region for the production of essential oils. Aerangis bovicornu has an EOO less than $100 \mathrm{~km}^{2}$ and an AOO less than 10 $\mathrm{km}^{2}$ and only one threat location is identified. In addition, the number of mature individuals is estimated to be less than 50 . The species is therefore assessed as Critically Endangered CR with Criterion D. FLOWERING TIME. December to January.

ETYMOLOGY. The epithet refers to the typical shape of the spur, resembling a bull's horn, especially that of the local Madagascan zebu cattle.

NOTES. The genus Aerangis Rchb.f. (Reichenbach 1865: 190) now comprises 59 species; they are largely epiphytes confined to Africa and the Madagascar region, apart from one species which occurs both in eastern Africa and Sri Lanka. There are 28 species in Madagascar, Réunion and the Comoros with 20 of them endemic to Madagascar. 

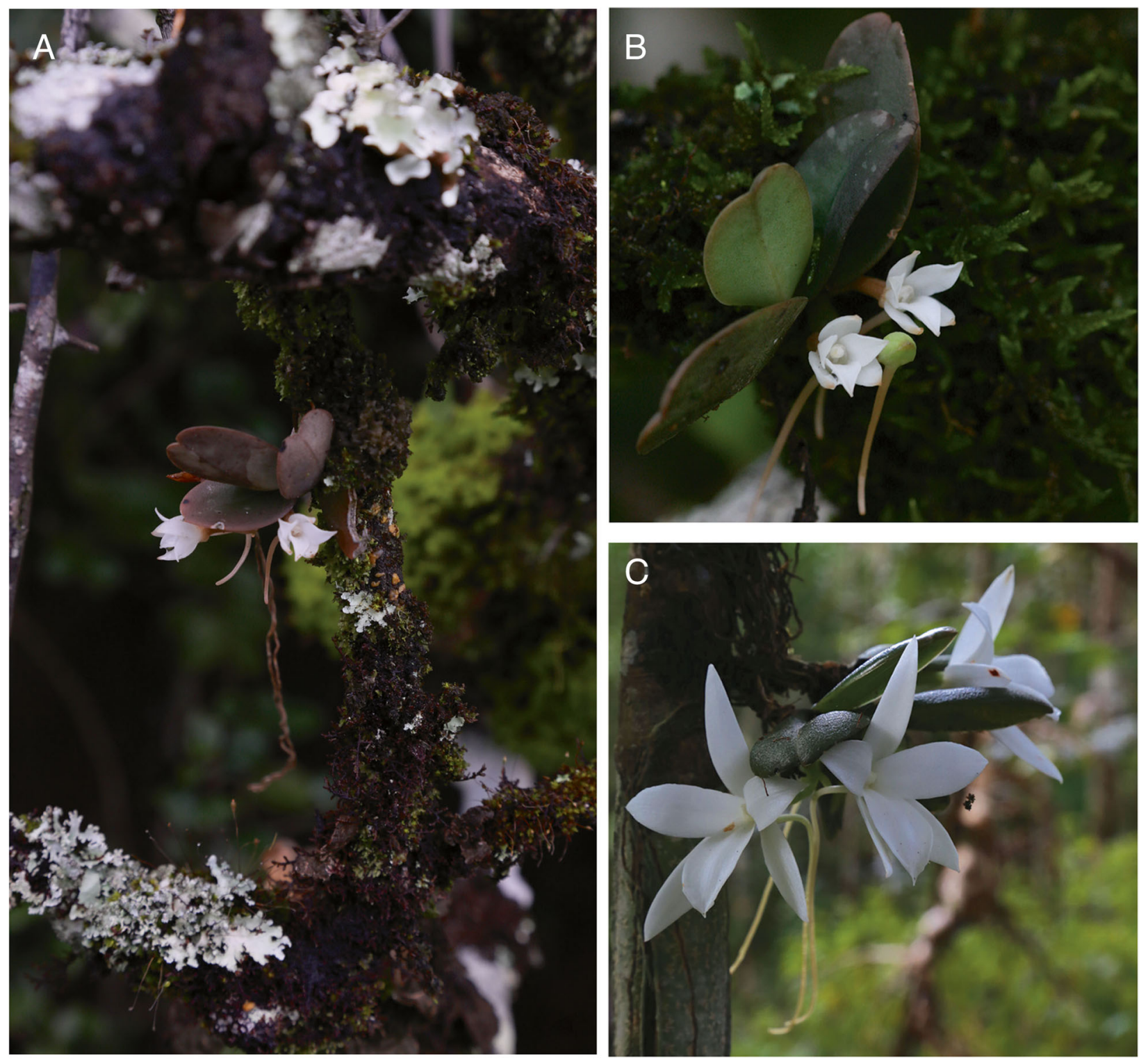

Fig. 1. A, B Aerangis bovicornu. A plant in habitat; B plant and flowers; C Aerangis fastuosa for comparison. PHOTOS: JOHAN HERMANS.

Aerangis fastuosa (Fig. 1C) was first described by $\mathrm{H}$. G. Reichenbach as Angraecum fastuosum Rchb.f. (Reichenbach: 1881c: 748) based on a plant collected by Léon Humblot in Madagascar and imported into England by the nurseryman Frederick Sander. The type specimen consists of two flowers and a drawing in the Reichenbach herbarium in W (number 46259). Reichenbach described it as having rugose leaves on the upper surface, a narrow lip and a long caudicula immersed in the spur. Two weeks later (Reichenbach 1881d: 844) added notes on a specimen from the same source and grown by Sir Trevor Lawrence, as equal to his type in all details, but having an obovate rounded lip, instead of a narrow acute one, and suggested either that M. Humblot's plant was a peloric form, or that there were two closely allied species. Joseph Hooker (1891: t.7202) later commented on Reichenbach's confusing descriptions. He added that the rugosity of the leaf occurs only after flowering and is hardly perceptible. He referred to the 1885 illustration of a Lawrence plant in Gardener's Chronicle (Masters 1885: 533) as a good likeness. Subsequently a great number of plants found their way into European collections and the variability of the species became evident as recognised by Perrier de la Bâthie in 1941 (pp. 93 - 95) when he described six varieties of the species, none being validly published because they lacked Latin descriptions. He also mentioned that they may well be separate species, all coming from different localities, a long way from each other. All are only 

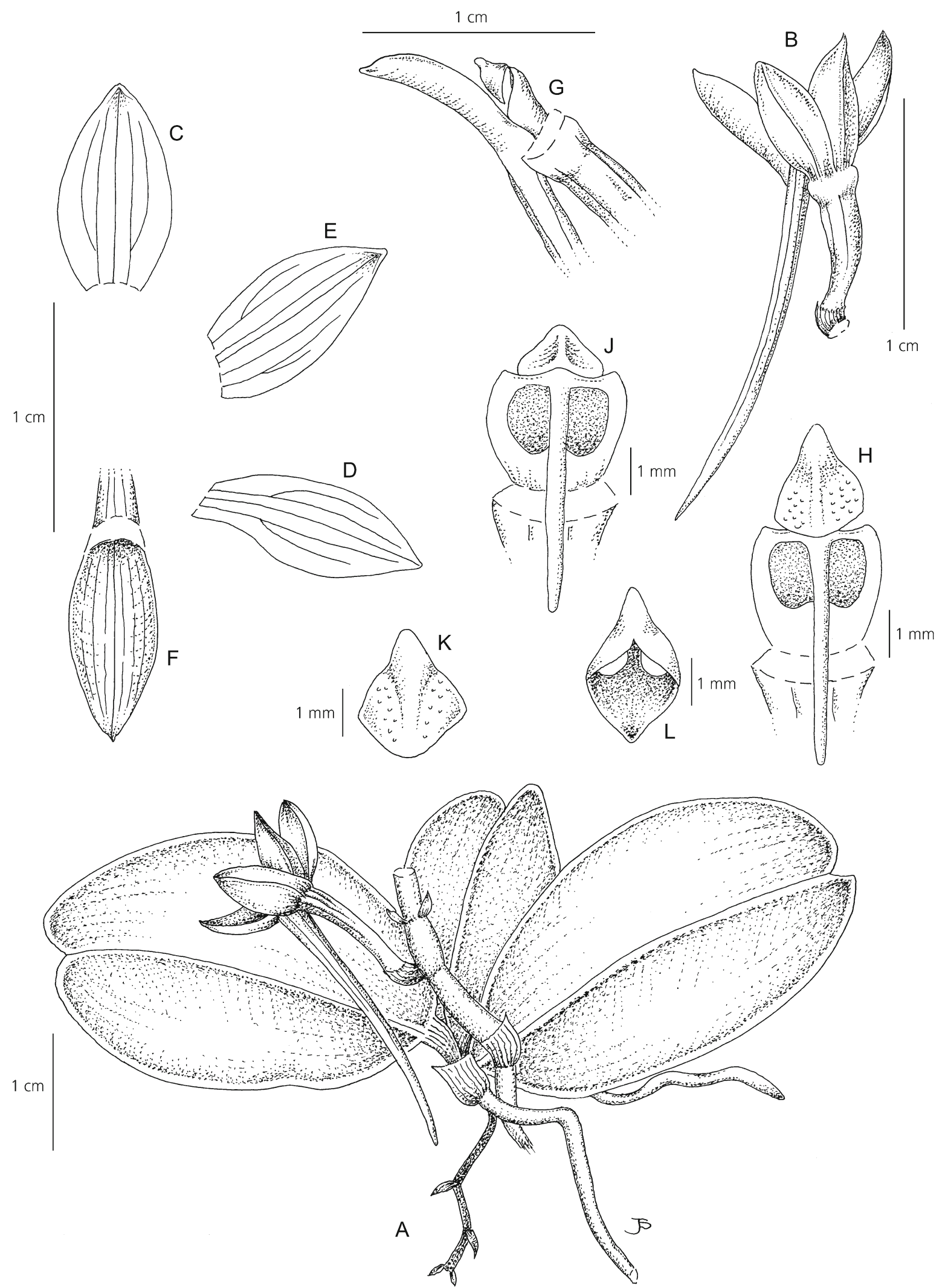

Fig. 2. Aerangis bovicornu. A habit; B flower; C dorsal sepal; D lateral sepal; E petal; $\mathrm{F}$ lip; $\mathrm{G}$ column and lip side view; $\mathrm{H}$ column, front view; J column, front view, anther cap removed; $\mathrm{K}$ anther cap, dorsal view; $\mathbf{L}$ anther cap, ventral view. From spirit material Hermans 8179. DRAWN BY JUDI STONE. 
Table 1. Comparison of differences and measurements of Aerangis bovicornu and A. fastuosa, based on 28 herbarium specimens and the types of the varieties of the latter.

\begin{tabular}{lll}
\hline \hline & Aerangis fastuosa & Aerangis bovicornu \\
\hline Dorsal sepal $(\mathbf{m m})$ & $17-36 \times 5.5-9$ & $7.8-8.6 \times 3.6-3.9$ \\
Lateral sepals $(\mathbf{m m})$ & $19-36 \times 5.5-8.5$ & $8.7-8.9 \times 3.5-3.7$ \\
Petals $(\mathbf{m m})$ & $19-34 \times 6-10$ & $8.3-8.6 \times 3.8-4.1$ \\
Lip $(\mathbf{m m})$ & $20-34 \times 5-13$ & $7.6-8.2 \times 3.9-4.1$ \\
Spur & $70-102 \times 1-1.8 \mathrm{~mm}$, generally coiled & $20-23 \times 0.9-1.3 \mathrm{~mm}$, straight \\
Column & $3-4 \times 2-3 \mathrm{~mm}$, apex broadened & $3-5 \mathrm{~mm} \times 1-3 \mathrm{~mm}$, apex narrow \\
Anther & $2.2-4 \times 1.8-2 \mathrm{~mm}$, conical with long beak & up to $1.4 \times 1.6 \mathrm{~mm}$, broadly obovoid \\
& & with a small rounded swelling at the apex \\
Flowering time & June to November & December to January \\
\hline
\end{tabular}

represented by very few herbarium specimens and it is difficult to define constant characteristics. Five of the varieties, notably var. francoisii, var. grandidieriana, var. maculata, var. rotundifolia and var. vondrozensis (Perrier 1941: 93 - 95) are generally accepted as local forms of one variable species (Stewart 1986a: 905; Hermans et al. 2007: 12; La Croix 2014: 149), the stated variation was mainly in the leaf shape and texture. The sixth, var. maculata (Perrier 1941: 95) was considered by Bosser (2006: 50) to be Aerangis punctata J.Stewart (1986b: 1120). A seventh, Aerangis fastuosa var. angustifolia H.Perrier (1941: 95), was considered an immature form of Aerangis modesta (Hook.f.) Schltr., (Schlechter 1914: 600). At first sight Aerangis bovicornu could be considered another local variant of Aerangis fastuosa, especially as it comes from a relatively accessible region but closer examination proves otherwise. They share the leaf shape, short rachis, shape of the perianth and the long rostellum but size of all the floral parts, spur length, column and anther shape and colour are all very different. Table 2 outlines the main characteristics of the different variants, none corresponding with Aerangis bovicornu. The characteristics of the new species were found to be consistent within the local colony of about 20 plants which consisted of plants with flowers that were just opening and others that had almost wilted.

Angraecopsis lemurelloides P.J.Cribb E Hermans sp. nov. Type: Madagascar, Antsiranana Prov., Andapa, Doany, Anjialavahely, Ankarongameloka forest, 1546 m, epiphyte on tree, March 2006, Antilahimena $\mathcal{E}^{\circ}$ Tianina 4742 (holotype K!, isotypes $\mathrm{P}$ !, TAN!).

http://www.ipni.org/urn:lsid:ipni.org:names:77214545-1

Arching to pendent epiphytic herb 15 - $21 \mathrm{~cm}$ long; roots basal, glabrous, greenish-white, $1-2 \mathrm{~mm}$ in diam. Stem woody, up to $15 \mathrm{~cm} \times 3-4 \mathrm{~mm}$, zigzag, flattened, the margins winged, carrying $12-17$ leaves, pale green with the lower part somewhat corrugate and brown. Leaves alter- nate, coriaceous, flat with an indistinct central vein, lanceolate-linear, $6.5-8.1 \times 0.5-0.8 \mathrm{~cm}$, narrowing towards the apex, attenuate, the base subcordate, surface somewhat glossy, pale green. Inflorescences emerging from the leaf-axils along the entire length of the stem, sometimes several produced from the same axil, $5-8 \mathrm{~cm}$ long, with $3-$ 7 flowers. Peduncle wiry, $3-5 \mathrm{~cm}$, c. $0.5 \mathrm{~mm}$ in diam., with a short thin, brownish bract at the base peduncle, $1-2$ peduncle sheaths c. $3 \times 1 \mathrm{~mm}$. Rachis loosely racemose, wiry, $3-5 \mathrm{~cm}$, somewhat zigzag. Floral bracts amplexicaul, $3.1-3.8 \times 1.1-1.4 \mathrm{~mm}$, green becoming brown with age. Flowers small, c. $7 \times 5 \mathrm{~mm}$, yellowish-green. Pedicel and ovary turbinate, $9-12 \times 1.3-1.6 \mathrm{~mm}$. Dorsal sepal convex, ovate, acute, $2.1-2.5 \times 1.9-2.2 \mathrm{~mm}$. Lateral sepals partly fused to the petals at the base, broadly lanceolate, acuminate with the tip reflexed, $3.1-3.4 \times 1.2-1.4$ $\mathrm{mm}$, margins recurved, the apex of the dorsal mid-vein mucronate before the apex of the leaf. Petals reflexed, ovate-triangular, acute, $1.4-1.7 \times 1.5-1.7 \mathrm{~mm}$, convex with a thickened mid-vein. Lip 3-lobed, $2.3-2.9 \times 2-$ $2.2 \mathrm{~mm}$, the hypochile orbicular beneath with the obtuse lateral lobes partly enveloping the column, the epichile broadly ovate, concave, somewhat bullate with a few fine hairs at the base; spur incurved below the flower, $4.9-5.4 \times 0.6-0.8 \mathrm{~mm}$, narrow at the opening, slightly thickened in the apical half. Column, fleshy, short, c. $1.6 \times 1.5 \mathrm{~mm}$; rostellum 3-lobed, wings sub-orthogonal, with an acicular median tooth; pollinia on separate viscidia, oblong, c. $1 \mathrm{~mm}$ long; anther cap elliptic, c. $0.6 \times 1.1 \mathrm{~mm}$. Seed capsule turbinate, c. $20 \times 5$ $\mathrm{mm}$, green. Figs 3 , 4 .

RECOGNITION. Angraecopsis lemurelloides is recognised by the long zigzag flattened stem with lanceolatelinear leaves alternate along its length, small flowers on the upper third of the serial wiry inflorescences, and flowers with petals and sepals that are fused at the base and with a mucronate tip to the mid-vein, the roundly 3-lobed lip with a concave epichile with wiry hairs at the base and the lateral lobes enveloping the column and a short inflated spur. 
Table 2. Main characteristics of the different variants of Aerangis fastuosa.

\begin{tabular}{|c|c|c|c|c|c|}
\hline & $\begin{array}{l}\text { var. francoisii } \\
\text { François } 12(\mathrm{P})\end{array}$ & $\begin{array}{l}\text { var. grandidieriana } \\
\text { Grandidier s.n. }(\mathrm{P})\end{array}$ & $\begin{array}{l}\text { var. maculata } \\
\text { Humbert } 11845(\mathrm{P})\end{array}$ & $\begin{array}{l}\text { var. rotundifolia } \\
\text { Decary } 5700(\mathrm{P})\end{array}$ & $\begin{array}{l}\text { var. vondrozensis } \\
\text { Decary } 5188(\mathrm{P})\end{array}$ \\
\hline Leaves (cm) & $1.8-3 \times 1.2-1.6$ & $4.5-6 \times 2-2.7$ & $1.5-2.7 \times 1-1.5$ & $2.5-3 \times 2.5$ & up to $6 \times 3$ \\
\hline Dorsal sepal (mm) & $18 \times 6$ & $22 \times 8$ & $19 \times 5.5$ & $27 \times 9$ & $17 \times 7$ \\
\hline Lateral sepals (mm) & $20 \times 6$ & $21 \times 7$ & $19 \times 5.5$ & $30 \times 9$ & $19 \times 7$ \\
\hline Petals (mm) & $19 \times 6$ & $22 \times 7$ & $19 \times 6$ & $19 \times 6$ & $19 \times 6$ \\
\hline $\operatorname{Lip}(\mathbf{m m})$ & $20 \times 8$ & $25 \times 5$ & $20 \times 9$ & $22 \times 8$ & $20 \times 5.5$ \\
\hline Spur (cm) & 7 & 8 & 7 & $\begin{array}{l}\text { Over } 6 \\
\quad(\text { damaged })\end{array}$ & Over 6 (damaged) \\
\hline Distribution & Central & SW coast & S Central & $\mathrm{SE}$ & SE \\
\hline $\begin{array}{l}\text { Main differences } \\
\text { from typical form }\end{array}$ & $\begin{array}{l}\text { leaves more rounded } \\
\text { and more obovate, } \\
\text { single flower }\end{array}$ & $\begin{array}{l}\text { leaves small, bracts } \\
\text { obtuse, spur long }\end{array}$ & $\begin{array}{l}\text { leaves small, } \\
\text { obovate-oblong } \\
\text { spotted with red }\end{array}$ & $\begin{array}{l}\text { leaves orbicular, } \\
\text { flowers larger }\end{array}$ & $\begin{array}{l}\text { bracts wide, lip } \\
\text { obovate, anther } \\
\text { obtuse }\end{array}$ \\
\hline
\end{tabular}

It is very different in plant habit and flower morphology from Angraecopsis parviflora (Thouars) Schltr. (Schlechter 1914: 601), the only other Angraecopsis Kraenzl. (Kraenzlin 1900: 171) recorded from Madagascar. That species has a stem that is always much shorter than the leaf, a lip with three distinct attenuate lobes and a slightly longer spur. In habit and inflorescence it somewhat resembles $A$. trifurca (Rchb.f.) Schltr. (Schlechter 1915: 428) from the Comoros but it has a much longer stem, carrying leaves along its length, the flowers being about half the size, the spur much shorter and the lip very different (three distinct attenuate lobes in A. trifurca). It is closest to Angraecopsis pobeguinii (Finet) H.Perrier (1941: 81) from the Comoros in flower size and in having a lip with small rounded lateral lobes but the plant of $A$. pobeguinii is much smaller $(3.5 \mathrm{~cm}$ long), the stem shorter ( $1 \mathrm{~cm}$ long), the leaves much smaller (c. $2 \mathrm{~cm}$ long), the spur is also much more clavate towards the apex.

DISTRIBUTION. Endemic to NE Madagascar.

SPECIMENS EXAMINED. MADAGASCAR. Anjialavahely, Ankarongameloka forest, $1546 \mathrm{~m}$, March 2006, Antilahimena E Tianina 4756 (paratypes MO, P!, TAN!).

HABITAT. Humid forest, epiphyte. Elevation c. 1550 m. CONSERVATION STATUS. Angraecopsis lemurelloides is distributed in N Madagascar, in Doany, Sava region, Antsiranana. With the AOO estimated to be $4 \mathrm{~km}^{2}$, one threat location identified and the number of mature plants, the species is assessed as Critically Endangered CR with criterion D.

FLOWERING TIME. March.

ETYMOLOGY. Refers to the similarity of the flowers to those of the genus Lemurella Schltr. (Schlechter 1925: 366).

NOTES. Morphologically the new species is somewhat ambiguous in its generic position. With a long stem, many wiry inflorescences and flowers with a threelobed lip with hairs at its base it resembles some species in the genus Lemurella and especially Lemurella culicifera (Rchb.f.) H.Perrier (1941: 334) but it lacks the non-resupinate flowers, has more flowers and the opening of the spur is narrow (vs funnel-shaped). It illustrates that the generic circumscription of both these genera is somewhat uncertain and needs further research. As determined by Bosser (2007), it fits more easily in the genus Angraecopsis. This genus, somewhat diverse and containing a confusing variety of species, was established by Kraenzlin (1900), based on Angraecopsis tenerrima Kraenzl. from Tanzania. Schlechter (1914 \& 1918a) extended the genus to seven species based on a spur with a narrow opening, entire side lobes of the lip and lip flat at the base, five being from mainland Africa and two from Madagascar, the Mascarenes and the Comoros. Perrier de la Bâthie (1941: 81) recognised five species in the Flore de Madagascar. Summerhayes (1951) in his revision of the genus recognised three sections: Angraecopsis, Cardiochilos and Coenadenium, mainly based on differences in the shape of the lip and column, with 14 species from the Afro-Madagascan region. Rasmussen (1978: 137) added further observations on the genus but doubted the generic and sectional

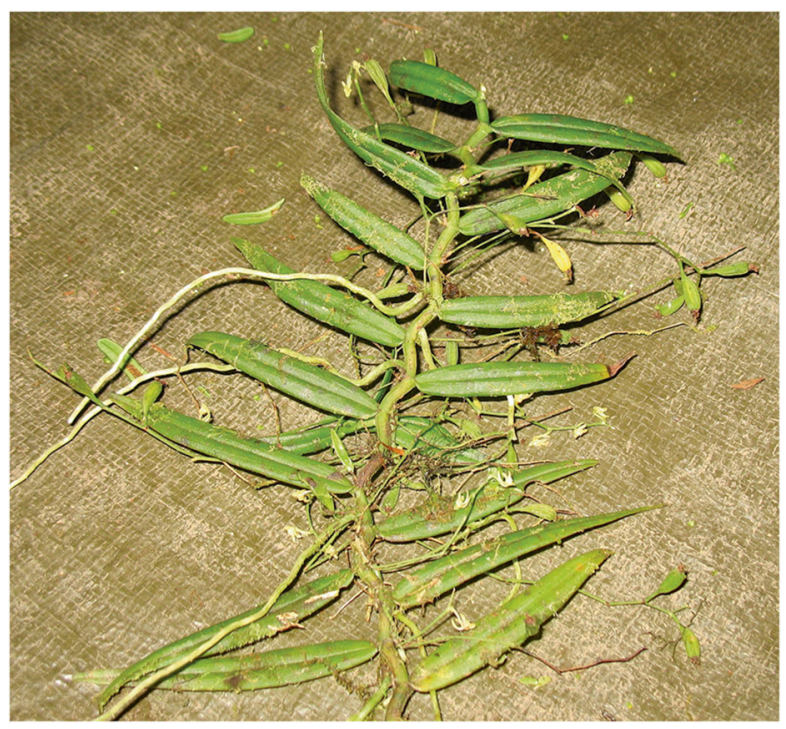

Fig. 3. Angraecopsis lemurelloides. Photograph of the syntype: Antilahimena \& Tianina 4756. PHOTO: (C) PATRICE ANTILAHIMENA. TROPICOS - MBG. 


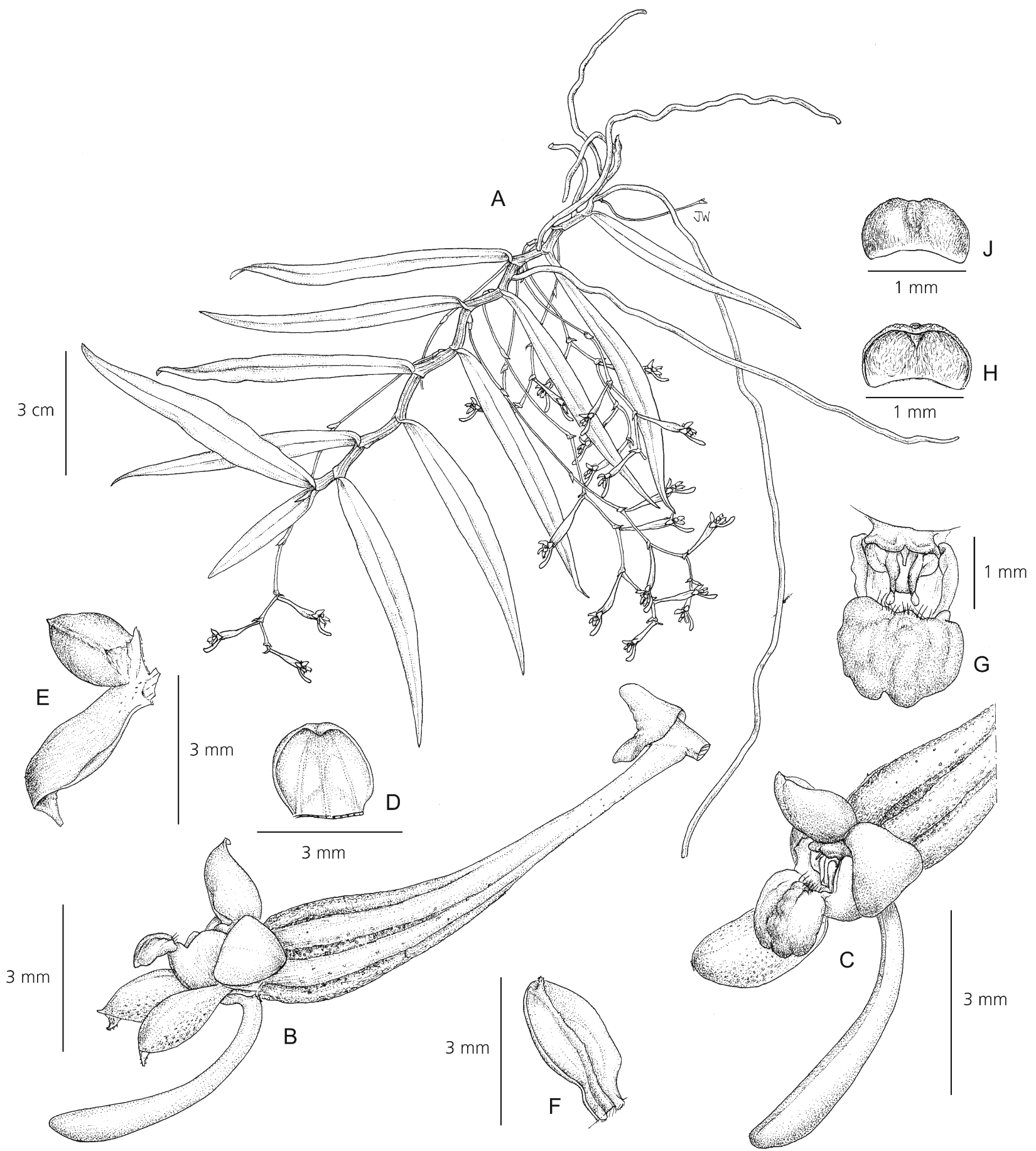

Fig. 4. Angraecopsis lemurelloides. A habit; B flower side view; C flower detail 3/4 view, lateral sepal removed, showing lip; D dorsal sepal, inside; E lateral sepal \& petal, above; $\mathrm{F}$ lateral sepal, underside; $\mathrm{G}$ front view lip, rostellum; $\mathrm{H}$ anther front view; J anther back view. Based on Antilahimena \& Tianina 4742. DRAWN BY JULIET BEENTJE.

circumscription. Recent molecular analyses by Martos et al. (2017) confirmed this view and proposed to restrict the concept of Angraecopsis to the species in section Angraecopsis, which includes all the species from the Madagascar region. The characteristics for the genus were summarised by Martos et al. (2017: 8) as: small to medium-sized plants with lateral sepals longer than the dorsal, a deeply three-lobed lip, a three-lobed glabrous rostellum with prominent lateral lobes and two pollinia each attached to a separate viscidium. Angraecopsis lemurelloides which is a relatively large plant with a long stem and roundly-lobed lip with hairs at the base only partly fits this definition but it does match it in the other aspects and also has the 
petals adnate to the lateral sepals as defined for the genus by Kraenzlin and Summerhayes. It is therefore placed in Angraecopsis but will remain a somewhat aberrant species.

Didymoplexis stella-silvae Hermans sp. nov. Type: Madagascar, Fianarantsoa prov., Mahakajy area, near Ifanadiana. c. 800 m, Dec. 1996, Hermans 8137 (holotype K!).

http:/ /www.ipni.org/urn:lsid:ipni.org:names:77214547-1

Erect holomycotrophic herb up to $9 \mathrm{~cm}$ tall, on a subterranean, stem-like rhizome, roots wiry, glabrous, c. $1.5 \mathrm{~mm}$ in diam. Rhizome terete, pale brown, elongate, a little verrucose, puberulent, ave. $12 \times 0.3$ $\mathrm{cm}$. Leaves scale-like, at the base of the inflorescence, c. $5 \times 3 \mathrm{~mm}$. Inflorescence erect as an uninterrupted continuation of the rhizomatous stem, with $1-2$ brown scarious scales towards the base. Peduncle slender, c. $1.5 \mathrm{~mm}$ in diam., with $2-3$ short nodes, otherwise smooth, brown, bearing a short $3 \mathrm{~mm}$ scale below the rachis. Rachis apical, racemose with $1-4$ flowers opening one at a time in succession. Floral bracts ovate, acute, $2-2.3 \times 1.4-1.6 \mathrm{~mm}$, verrucose abaxially. Flowers resupinate, spreading, reclining, overall $18-19 \times 14 \times 16 \mathrm{~mm}$, crystalline white except for the yellow-orange lip callus and base, the lip with a greenish-yellow triangle abaxially. Pedicel and ovary fusiform, $8-11 \times 0.8-1.1 \mathrm{~mm}$, with longitudinal ridges during flowering, minutely verrucose, pale brown. Dorsal sepal connate to the petals for 2 $3 \mathrm{~mm}$ at the base, erect, broadly lanceolate, $8.1-8.5 \times$ $4-4.3 \mathrm{~mm}$, subacute, verrucose-warty on the exterior. Lateral sepals connate to each other at the base for c. 3 $\mathrm{mm}$, spreading, ovate, $9.8-10.2 \times 5-5.5 \mathrm{~mm}$, obtuse to subacute. Petals oblanceolate, $6.9-7.2 \times 3.8-4 \mathrm{~mm}$, acute, partly adnate to the dorsal sepal. Lip with a strap-like $3-5 \mathrm{~mm}$ foot at the base, blade then reniform, truncate, margins curved, undulate, becoming serrate towards the anterior part, overall $5.1-5.3 \times$ $9.1-9.3 \mathrm{~mm}$, base claw-like, extended into a bilobed callus irregularly laciniate at the anterior margin, the blade with two irregular longitudinal rows of long thorn-like hairs, the entire lip mobile and seems to retract back against the column, during or after fertilisation. Column slender at the base, with short, triangular stelidia and with obovate, rounded arms just below the stelidia, $3.8-4 \times 3.4-3.5 \mathrm{~mm}$; anther elliptic, disk-like, c. $1.2 \times 1.9$ mm. Figs 5,6 .

RECOGNITION. Didymoplexis stella-silvae is a holomycotrophic plant with a thin erect inflorescence carrying few flowers opening successively and one at a time. The petals are adnate to the dorsal sepal and the lateral sepals adnate to one another. The mobile truncate reniform lip, undulate to laciniate at the margin, has two rows of thorn-like hairs, a bilobed callus becoming laciniate at the front, and a column with obovate, rounded arms just below the stelidia. The new species has some characteristics in common with a number of other Didymoplexis species but there are also several distinct differences. In the Africa - Madagascar region it has flowers about half the size of D. avaratraensis P.J.Cribb, Nusb. \& L.Gaut. (Cribb et al. 2013: 43) and D. africana Summerh. (Summerhayes 1952: 465): the petals and sepals are also less fused, while the lip adornments and shape and callus are also very different. It has a similar habit and flower colour to $D$. verrucosa J.Stewart \& Hennessy (1980: 841), but D. stella-silvae has 1 -4 flowers (vs $8-12$ ), the sepals and petals are connate (vs fused to the middle), the lip reniform (vs transversely triangular) and two rows of long hairs on the lip (vs lines of warts from base to tip). It is closest to Didymoplexis recurvata P.J.Cribb, Nusb. \& L.Gaut. (Cribb et al. 2013: 44), recently described from northern Madagascar which is comparable in size and colour, the petals and sepals adnate toward their base, its lip shape and column wings being similar but $D$. stella-silvae has narrower petals, and the lip larger and broader $(3.5-4 \times 5-6 \mathrm{~mm}$ vs $5.1-$ $5.3 \times 9.1-9.3 \mathrm{~mm})$. Didymoplexis recurvata also lacks the rows of long hairs on the disk and has a 3-lobed callus at the base (vs 2-lobed).

DISTRIBUTION. Endemic to eastern Madagascar, Fianarantsoa province, around Ifanadiana and Ranomafana National Park.

SPECIMENS EXAMINED. MADAGASCAR. Without specimen: observed by one of the authors $(\mathrm{JH})$ and other researchers in Ranomafana National Park, at c. 1000 m. HABITAT. Humid evergreen forest, in deep shade, in leaf litter and humus. Elevation 800 - 1070 m.

CONSERVATION STATUS. Recent observations of several colonies by one of the authors (JH) found an increasing threat by two different species of bamboo in the area; one tall Bambusa with its fallen leaves covering the forest floor and a smaller species forming an equally impenetrable mass. Some Asian Didymoplexis species are associated with bamboo but this may not be the case for this species as it was only found some distance away from invasive bamboos. Didymoplexis stella-silvae is distributed in SE Madagascar in the Vatovavy-Fitovinany region, Fianarantsoa. With two threat locations, found within the Ranomafana Protected Area, the extent of occurrence is estimated to be less than $5000 \mathrm{~km}^{2}$ and the area of occupancy less than $500 \mathrm{~km}^{2}$, in continuing decline due to habitat destruction caused by fire, the species is therefore assessed as Endangered EN under criteria Blab(i,ii,iii) $+2 \mathrm{ab}(\mathrm{i}, \mathrm{ii}, \mathrm{iii})$.

FLOWERING TIME. December to January. ETYMOLOGY. The name refers to the bright white flowers, resembling stars appearing on the forest floor. 

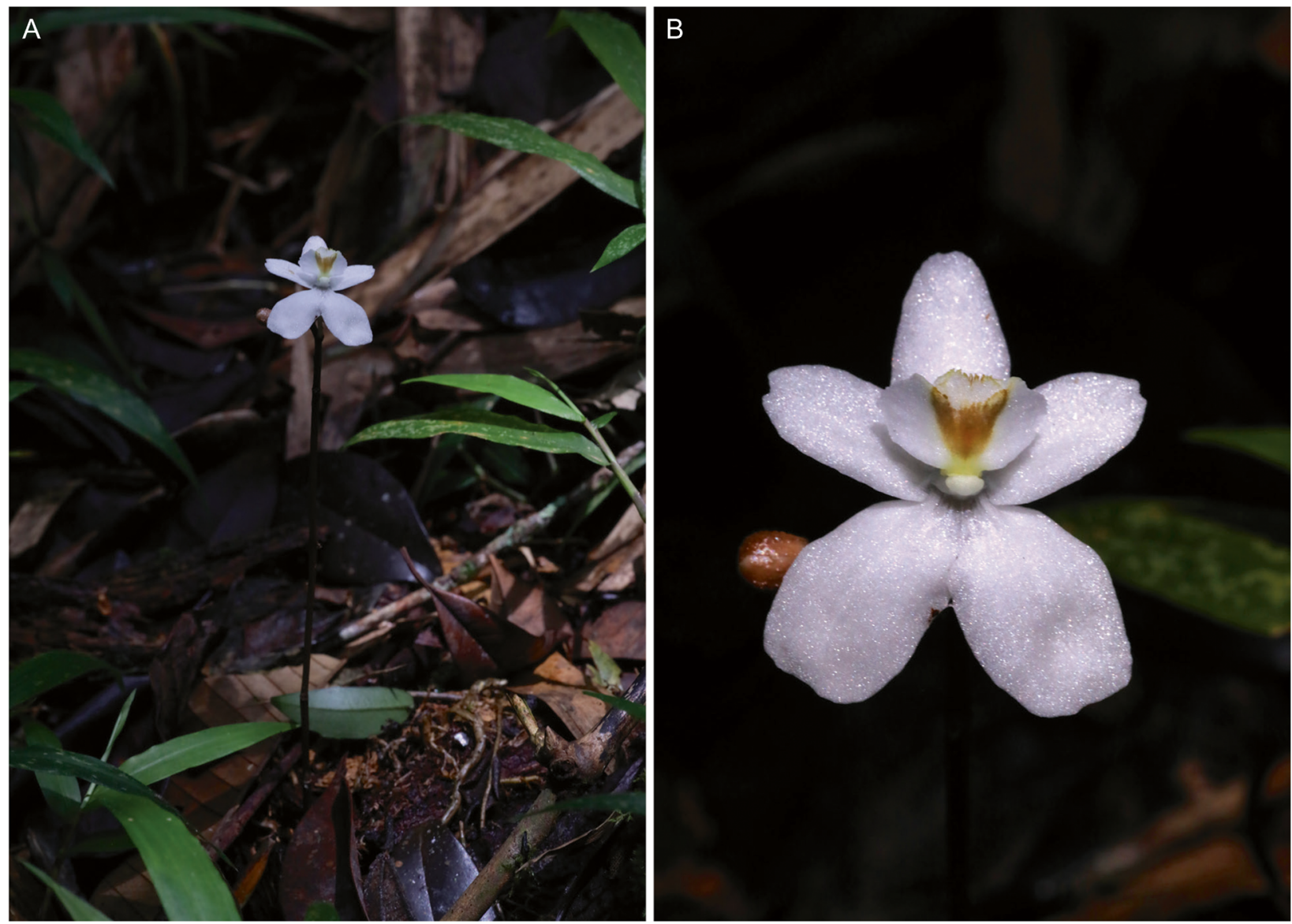

Fig. 5. Didymoplexis stella-silvae. A plant in habitat; B detail of flower. PHOTOS: JOHAN HERMANS.

NOTES. Didymoplexis Griff. (Griffith 1844: 383) is a genus of 21 terrestrial, holomycotrophic, achlorophyllous species found in tropical and southern African, tropical Asia from India and the Ryukyu Islands eastwards through Malesia to Australia and the Pacific archipelagos to Fiji and Samoa (Govaerts 2019). Until 2011 no true Didymoplexis had been recorded from Madagascar (D. madagascariensis (Schltr. ex H.Perrier) Summerh. (Summerhayes 1953: 131) is now considered Gastrodia madagascariensis Schltr. ex Martos \& Bytebier (Martos et al. 2015: 048). Cribb et al. recorded D. verrucosa from northern Madagascar in 2011 (Cribb et al. 2011) and two years later (Cribb et al. 2013) described D. avaratraensis and $D$. recurvata, also from northern Madagascar and wondered how many species of Didymoplexis there were on the island. Didymoplexis stella-silvae is another surprising discovery and brings the total to four, it is the first to be found in the central eastern forest of the island. The bright star-white flowers stand out in the deep shade of the forest; recently small colonies were observed and photographed in the Ranomafana National Park in a very well researched area near one of the main paths. It is likely that the species has rarely been seen because it has no leaves and the flowers only seem to open immediately after a significant rain shower and only remain open for less than a day, new flowers then open after the next rain shower. The pollination and lip mechanism deserves further research: the lip is hinged on a thin strap-like foot and was observed to retract against the column in a number of flowers, it is possible that the lip and its hairs act as a simple balance and flip back when visited by pollinators, it also possible that it just retracts after pollination has been effected or it may even be a trapping mechanism as has been observed in the South American orchid genus Porroglossum Schltr. (Schlechter 1920: 82).

Habenaria crocodilium Hermans sp. nov. Type: Madagascar, Toamasina Prov., Andasibe, forest around Vakona Lodge, 950 m, Sept. 1996, Hermans 4880 (holotype $\mathrm{K} !)$.

http:/ /www.ipni.org/urn:Isid:ipni.org:names:77214548-1

Erect terrestrial herb $20-40 \mathrm{~cm}$ tall without the inflorescence, with two ellipsoid tubers, c. $2.5-3 \mathrm{~cm}$ long, hirsute, roots wiry, clustered around the base of the stem c. $3 \mathrm{~mm}$ in diam. Stem not branched, $10-30 \times 0.5-$ $0.8 \mathrm{~cm}$ with $3-4$ leaf-like sheaths along its length dividing it into short segments, becoming progressively 


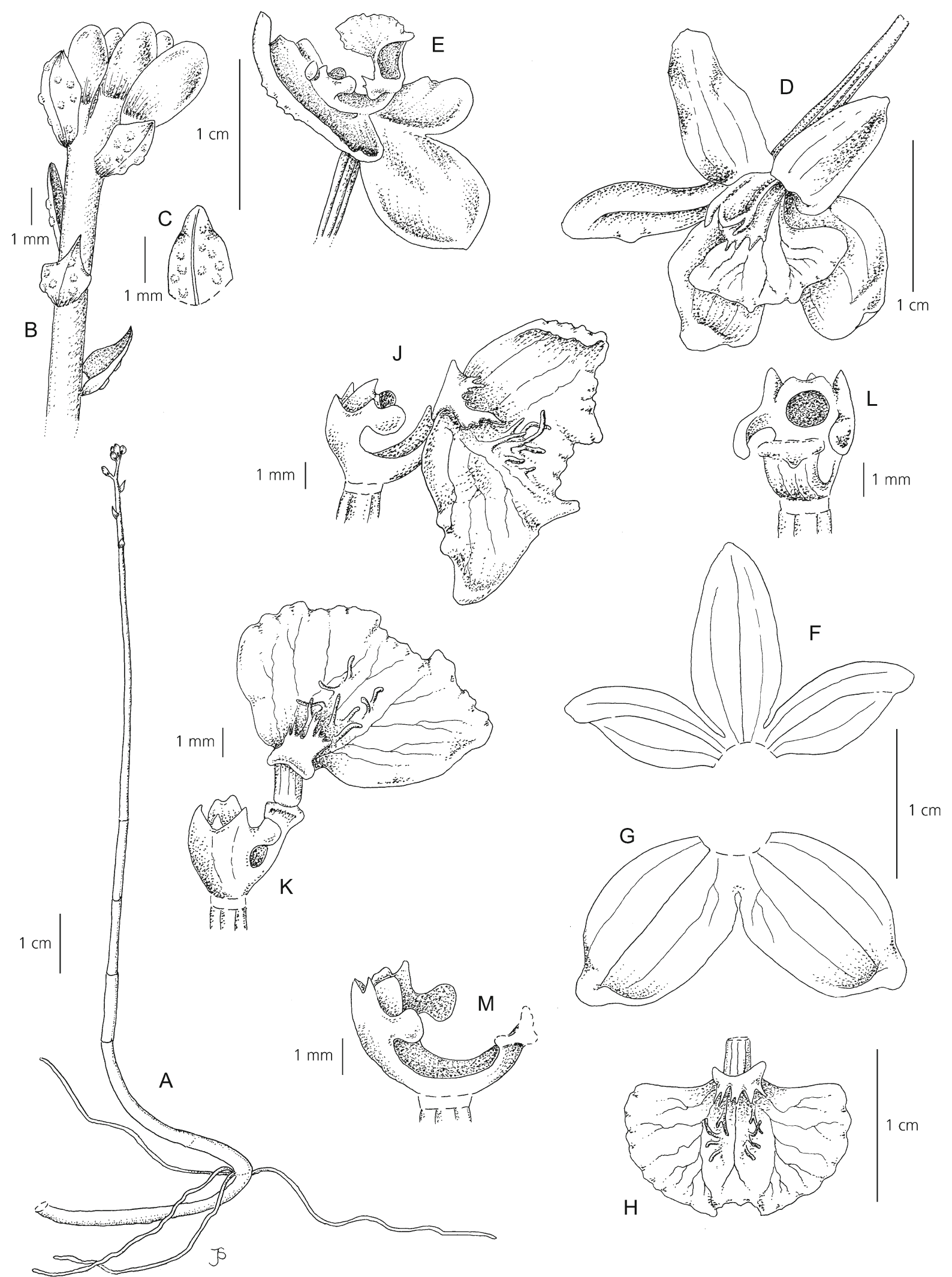

Fig. 6. Didymoplexis stella-silvae. A habit; B inflorescence; C bract; D flower, front view; E flower, side view; F dorsal sepal \& petals; G lateral sepals; H lip; J column \& lip, side view; K column \& lip from above; L column, front view; M column, side view. Based on Hermans 8173. DRAWN BY JUDI STONE. 
larger toward the top, $3-8 \times 1-3.5 \mathrm{~cm}$. Leaves spreading, $3-5$, arranged spirally along the stem forming an apical crown, lanceolate, $7-18 \times 1.2-$ $2.8 \mathrm{~cm}$ flat, somewhat fleshy, attenuate, subcordate at the base, shortly petiolate, somewhat serrate at the margins, pale green, darker along the veins. Inflorescence terminal, c. $15 \mathrm{~cm}$, laxly racemose with c. 15 flowers. Peduncle c. $10 \mathrm{~cm}, 2-4 \mathrm{~mm}$ in diam., with $1-2$ ovate sheaths, attenuate, subcordate at the base, hirsute, c. $20 \times$ $8 \mathrm{~mm}$. Floral bracts lanceolate, conduplicate, attenuate, dentate to hirsute at the dorsal ridge and basal margins, $11-16 \times 2.1-3.2 \mathrm{~mm}$. Flowers evenly distributed along the rachis, spreading, overall c. $25 \times 25 \mathrm{~mm}$, all segments pale green becoming paler towards the centre, the veins a little darker, column white, pollinia yellow. Pedicel and ovary fusiform, sharply ridged, densely denticulate, pale green, $15-21 \times 1.2-2.5 \mathrm{~mm}$. Dorsal sepal cucullate, arching over the column, lanceolate, $10-12 \times 4.5-5$ $\mathrm{mm}$, the exterior echinate along the mid-vein. Lateral sepals spreading, obliquely ovate, $11.2-11.6 \times 6-6.2$ $\mathrm{mm}$, almost flat, the apex a little mucronate, the veins thickened. Petals bifid to the base, posterior lobe (11 $12.1 \times 1.1-1.4 \mathrm{~mm}$ ) adnate to dorsal sepal, ligulatelinear, attenuate, anterior lobe $(9.3-12 \times 1.2-1.3 \mathrm{~mm})$ spreading to curved. Lip 3-lobed, all lobes pendent recurved, the mid-lobe more strongly recurved especially at the tip, linear falcate, attenuate, mid-lobe $(11-14.2 \times$ $0.7-0.9 \mathrm{~mm})$, lateral lobes $(15.7-14.3 \times 1.1-1.4 \mathrm{~mm})$; spur clavate, tubular in the basal half, thickened and laterally compressed in the apical half, 12.3 - 13.1 × $1.2-$ $1.9 \mathrm{~mm}$. Column c. $5 \mathrm{~mm}$ high, $9 \mathrm{~mm}$ long, anther loculi narrowly ovoid, anther channels distinctly up-curved, c. $6.7 \times 0.3 \mathrm{~mm}$, stigmatic lobes linear incurved, staminodes bilobed, verrucose, pollinarium c. $8 \mathrm{~mm}$ long. Figs 7, 8 .

RECOGNITION. Habenaria crocodilium is distinct in being a tall plant with spirally arranged leaves forming an apical crown, having an inflorescence borne on a short peduncle, denticulate floral bracts and flowers that are large for the genus in Madagascar, with denticulate ovary ridges, bifid petals with equal lobes, a lip with three equal descending lobes, a slightly flattened clavate spur shorter than the pedicellate ovary, and long and strongly up-curved anther channels. Amongst the large and medium-sized-flowered species of Madagascar and mainland Africa it is somewhat similar in flower shape to $H$. beharensis Bosser (1969a: 293), H. cirrhata (Lindl.) Rchb.f. (Reichenbach 1865: 180) and H. clavata (Lindl.) Rchb.f. (Reichenbach 1865: 180) but it is very distinct in its habit with its leaves borne along the stem (vs apical), and much smaller flowers (half the size) with a much shorter and differently shaped spur. It has a similar spur and anther-channel shape to $H$. cornuta Lindl. (Lindley 1837: 208) but again differs by its distinct habit, smaller flowers and differently proportioned lip and petals. The short clavate spur is also found in H. cochleicalcar Bosser (1969a: 294), and its flowers are also similar in size but the habit of $H$. crocodilium is different and the lobes of the petals and lip are of different proportions (unequal vs equal). It is similar in plant habit to $H$. tianae P.J.Cribb \& D.L.Roberts (2008: 199) but its flowers are smaller by at least $1 /{ }_{3}$, the spur much shorter (12 mm vs $12 \mathrm{~cm}$ ) and the anther channels a different shape. None of the other species listed above have the pronounced echinate-denticulate ovary, floral bract and exterior of the dorsal sepal.

DISTRIBUTION. Known from two localities in Toamasina province, the type location in the eastern forest and another in NE Madagascar.

SPECIMENS EXAMINED. MADAGASCAR. Toamasina, Analanjirofo, Lohan'i Ambitsy forest, Makira, $808 \mathrm{~m}$, July 2007, Antilahimena et al. 5672 (TAN!).

HABITAT. Humid evergreen forest, on riverbanks and wet areas. Elevation 800 - 950 m.

CONSERVATION STATUS. Habenaria crocodilium is distributed in E Madagascar, in the Alaotra-Mangoro and Analanjirofo regions, Toamasina province. Two threat locations were identified, although the two subpopulations are protected in Makira and Vakona lodge, the species habitat quality is continuing in decline due to shifting agriculture and forest logging. Recently, colonies in the type locality were destroyed by landslides. The species is therefore assessed as Endangered EN Blab(iii) +2ab(iii).

FLOWERING TIME. July to September.

ETYMOLOGY. Referring to the type locality near a crocodile enclosure and the resemblance of the column and dorsal sepal to the head of a crocodile, plus the numerous teeth on the flowers and ovary.

NOTES. Habenaria Willd. (Willdenow 1805: 44) is a genus of about 600 terrestrial orchids, widely distributed in tropical and subtropical regions of the Old and New World (Cribb in Pridgeon et al. 2001: 300). There are now a total of 48 Habenaria species recognised from the Madagascar, Mascarene and Comoro region, 33 of which are found on Madagascar. Twenty-eight Habenaria species are endemic to Madagascar.

Polystachya siederi Hermans sp. nov. Type: Madagascar, Mahajanga prov., Bealanana area, $924 \mathrm{~m}$, Jan. 2017, Sieder, Pertl, Prehsler E $\mathcal{F}$ Andriantiana 7112 (leg. Hermans 8151), (holotype WU!).

http:/ /www.ipni.org/urn:lsid:ipni.org:names:77214549-1

A large erect creeping lithophytic herb up to $18 \mathrm{~cm}$ high, on a very short rhizome with the new growth emerging from the base or node of the old pseudobulbs, with a dense mass of thick glabrous greyish roots $2-3 \mathrm{~mm}$ in diam. Pseudobulbs conical to 

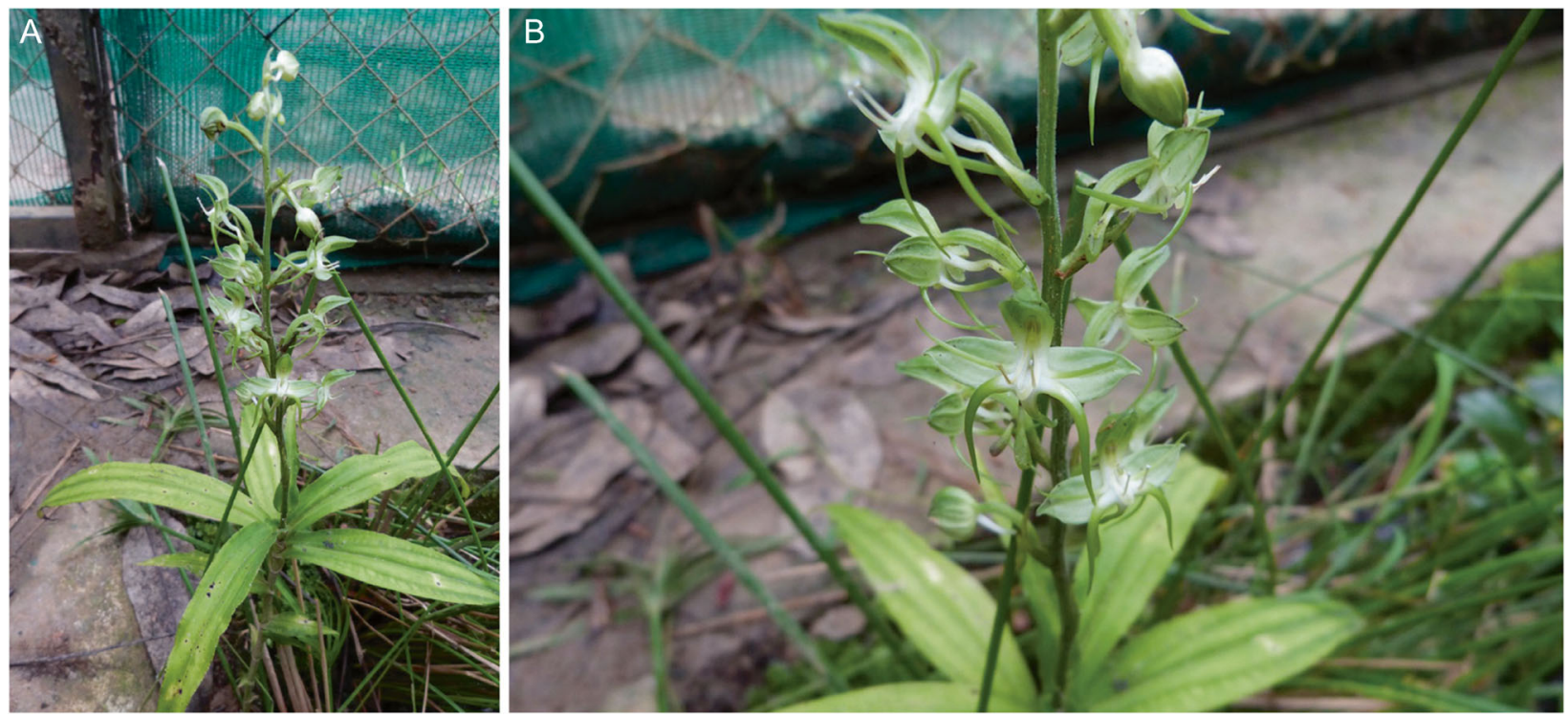

Fig. 7. Habenaria crocodilium. A plant habit; B inflorescence and detail of flower. PHOTOS: MAG IZOUARD.

subcylindrical, $35-60 \times 4-7 \mathrm{~mm}$, longitudinally ridged, the older ones distinctly annulate at the old leaf joints, partly covered by several overlapping greyish-brown sheaths, $3-4$ leaves towards the apex. Leaves linear-ligulate, attenuate at the tip, $8-15 \times 1.2-$ $1.5 \mathrm{~cm}$, narrowed into a conduplicate petiole at the base, the basal one much smaller and almost bractlike, pale green. Inflorescence erect, surpassing the leaves, up to $18 \mathrm{~cm}, 1.2-2.1 \mathrm{~mm}$ in diam., densely racemose in the apical third with up to 9 flowers. Peduncle flattened - laterally compressed, almost glabrous towards the base but becoming echinatehirsute towards the rachis, generally with a prominent conduplicate leaf-like scale towards the middle (35 $65 \times 4-6 \mathrm{~mm}$ ) and $2-4$ thinner and much shorter amplectant sheaths. Rachis terete, not branched, $3-6$ $\mathrm{cm}$, flowering in succession, hirsute. Floral bracts lanceolate acuminate, persistent and thickened at the base, hirsute on the exterior especially towards the base, $3-3.2 \times 1.5-2.1 \mathrm{~mm}$. Flowers c. $10 \times 9 \mathrm{~mm}$, pure white except for the orange callus in the middle of the lip and farinose orange-yellow patch on the mid-lobe of the lip, the white ovary becoming green on fertilisation. Pedicel and ovary glabrous, fusiform, longitudinally ridged, $4.8-5.2 \times 1.1-1.3 \mathrm{~mm}$. Dorsal sepal ovate, acute, $5.1-5.5 \times 3.4-3.7 \mathrm{~mm}$, arching over the column. Lateral sepals spreading, forming an indistinct rounded mentum with the column foot, ovate, shortly acuminate, $5.4-5.6 \times 5.4-5.9 \mathrm{~mm}$. Petals oblanceolate, $4.2-4.3 \times 1.9-2 \mathrm{~mm}$, acute, incurved. Lip $5.1-5.3 \times 4.9-4.8 \mathrm{~mm}$, 3-lobed in the apical half, the lateral lobes porrect elliptic obtuse, the mid-lobe sub-triangular, ending in a short incurved apicule, margins rounded, the disc and mid-lobe minutely pubescent-farinose, disk with a distinct ovoid to almost globular callus in the centre, densely covered in farina. Column stout, 3-lobed, stigma rounded, transversally oblong, $2.5-3 \times 1.5-1.6$ $\mathrm{mm}$; anther hemispherical with a rounded apical lobe, c. $1.1 \times 1.2 \mathrm{~mm}$; pollinia (2) ovoid, c. $0.8 \times 0.6 \mathrm{~mm}$. Seed capsule fusiform, c. $15 \times 5 \mathrm{~mm}$. Figs 9, 10 .

ReCOGNITION. Polystachya siederi is distinct in having ascending pseudobulbs on a very short rhizome, large leaf-like scales towards the middle of the inflorescence, an unbranched inflorescence densely racemose towards the apex, hirsute rachis and floral bracts, medium-sized flowers with ovate lateral sepals forming a short rounded mentum at the base, a lip three-lobed in the apical half, and a farinose disk with an ovoid to globular callus in the centre. Amongst the Polystachya Hook. (Hooker 1824: t.103) species occurring in Madagascar, $P$. siederi has some vegetative and floral similarities to $P$. anceps Ridl. (Ridley 1885: 473), P. heckeliana Schltr. (Schlechter 1913: 167) and P. rhodochila Schltr. (Schlechter 1916: 323) but it differs in having an unbranched inflorescence, slightly smaller flowers, and more oval lateral sepals and lip shape; it also has much shorter floral bracts than $P$. rhodochila. In flower shape it is most similar to $P$. heckeliana but the lip is lobed in the apical half (vs the basal half), the callus is more distinct and the flower colour is also different. It shares a number of characteristics with several Polystachya from mainland Africa: the inflorescence, lip shape and callus are most similar to P. transvaalensis Schltr. (Schlechter 1895: 28) and P. albescens Ridl. (Ridley 1887: 199) and its variants but it is distinct from both by its shorter and broader pseudobulbs, unbranched inflorescence, and slightly smaller flowers with shorter and more rounded ovate lateral sepals. 


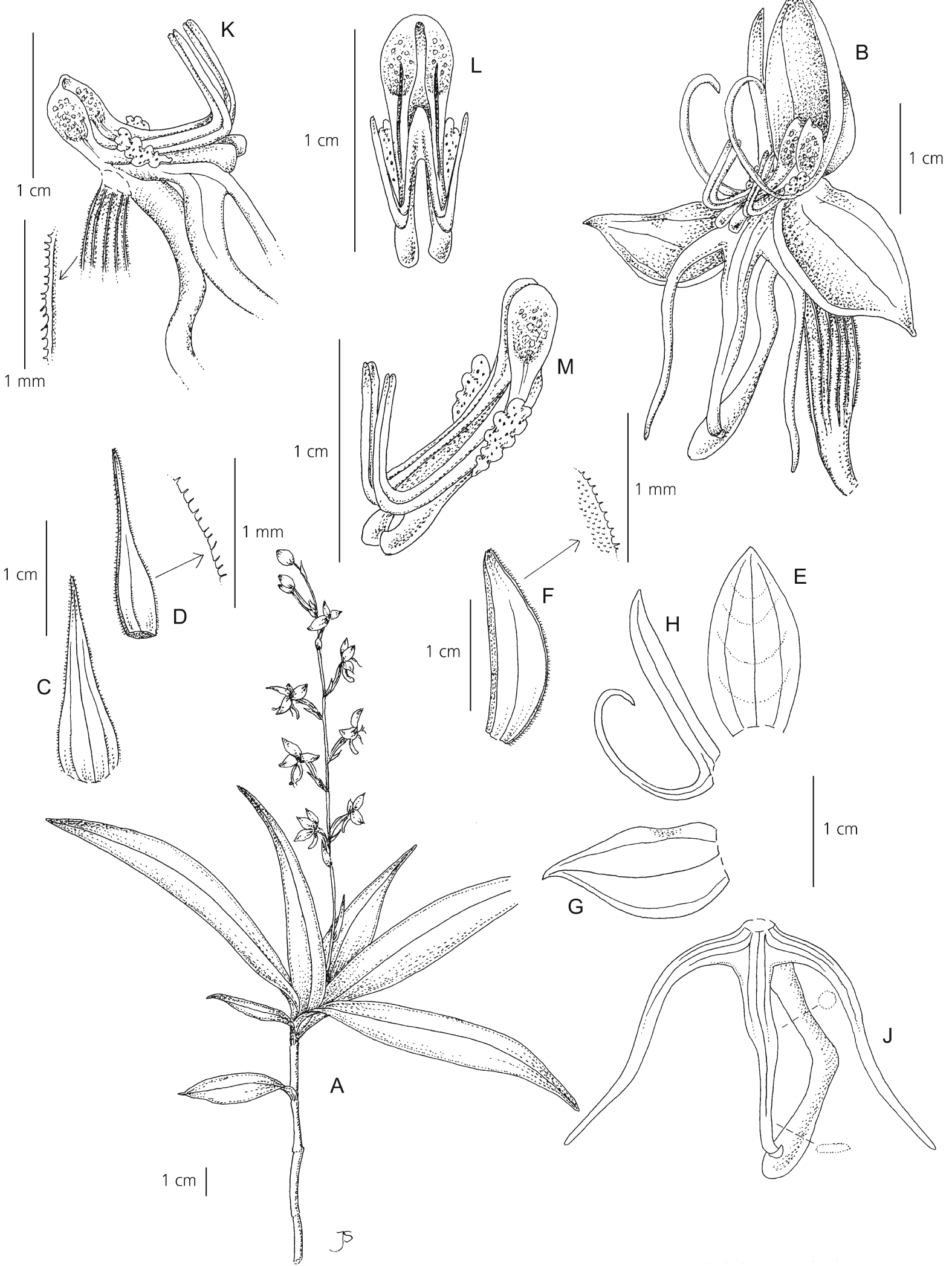

Fig. 8. Habenaria crocodilium. A habit; B flower; C bract, dorsal view; D bract, side view; E dorsal sepal, front view; F dorsal sepal, side view; G lateral sepal; H petal; J lip; $\mathrm{K}$ column and lip, side view; L column, from above; $M$ column, side view. Based on Hermans 4880. DRAWN BY JUDI STONE. 

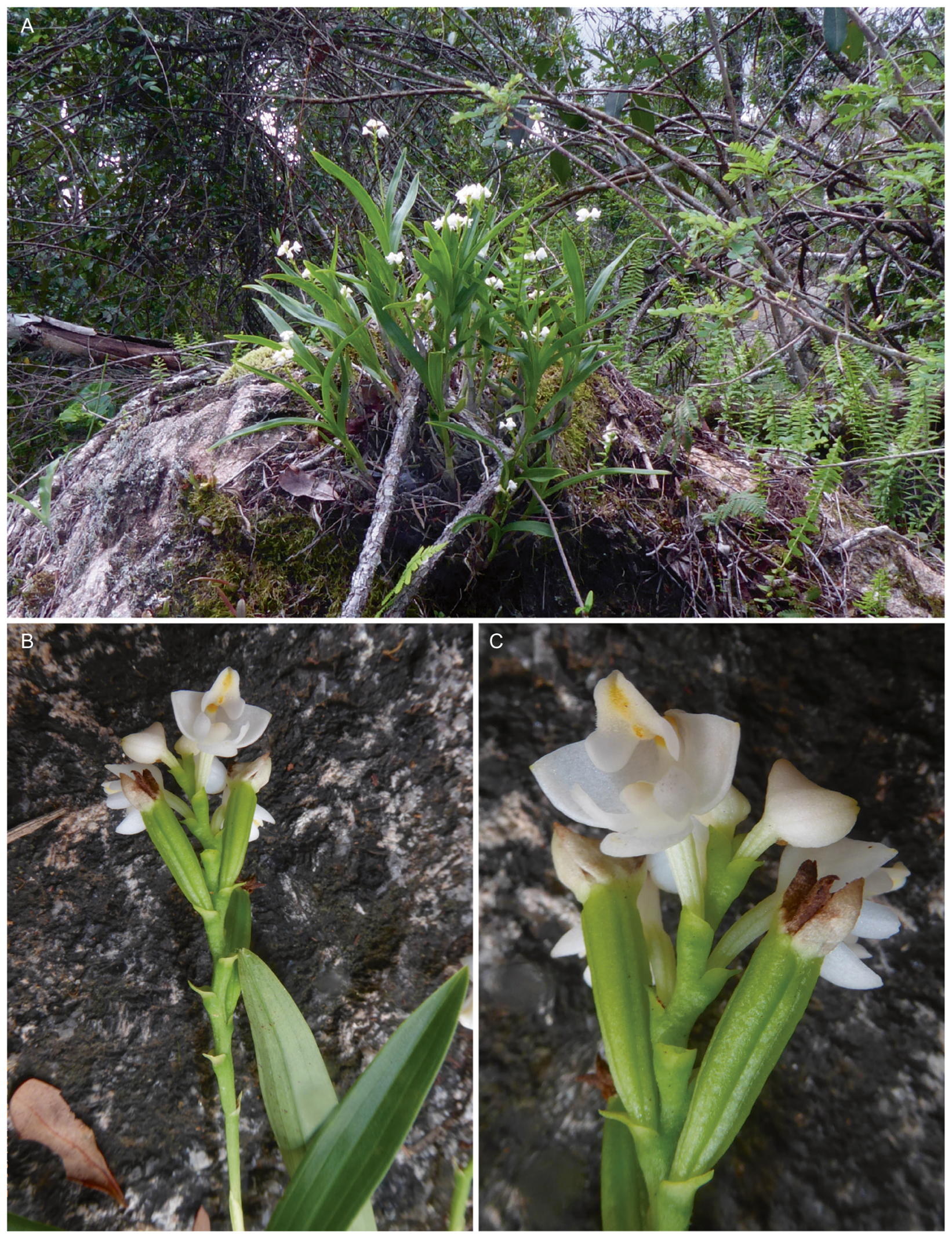

Fig. 9. Polystachya siederi. A plant in habitat; B part of the rachis C detail of flower. PHOTOS: ANTON SIEDER. 


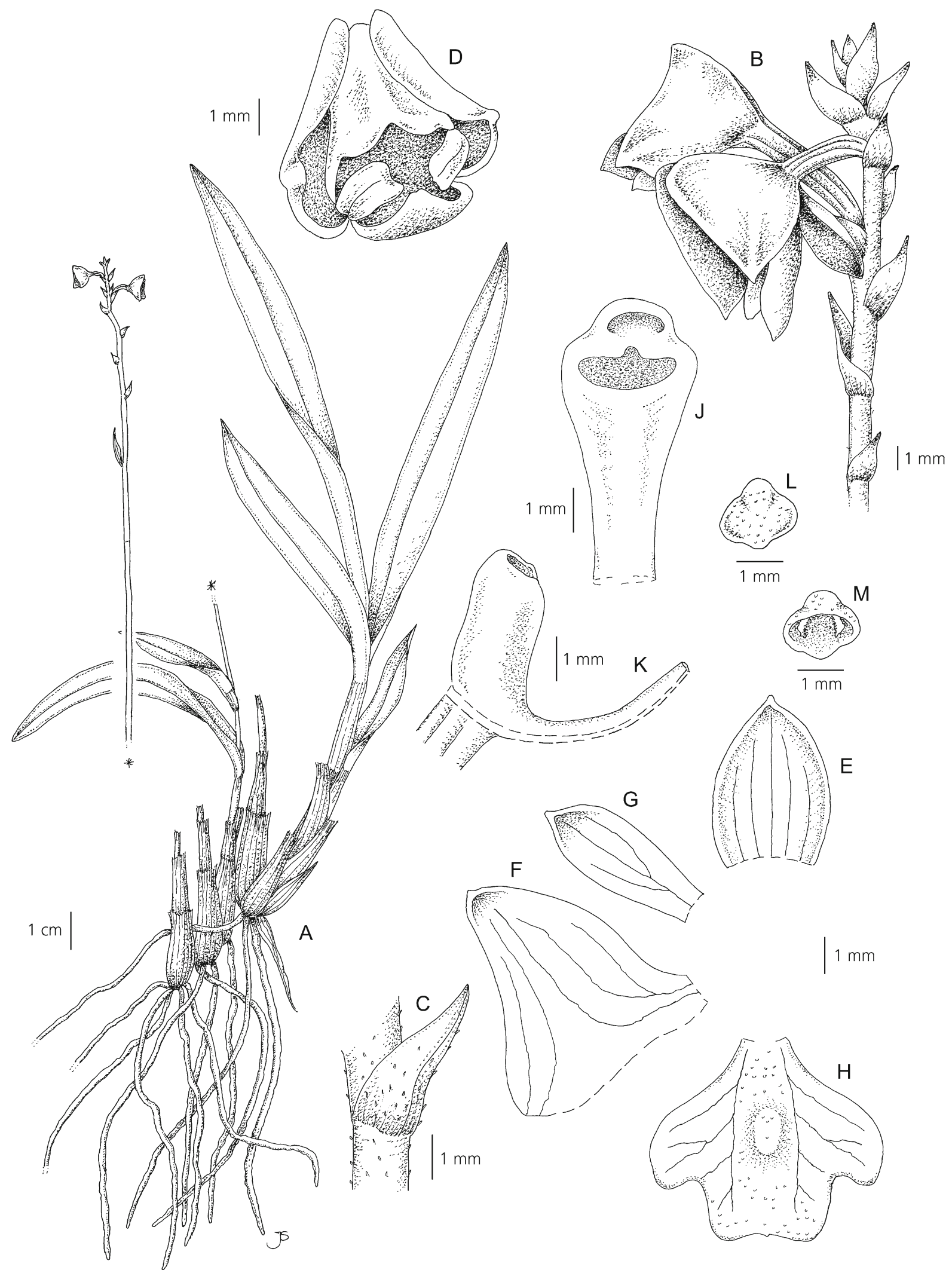

Fig. 10. Polystachya siederi. A plant habit; B inflorescence; C floral bract, enlarged; D flower front view; $\mathbf{E}$ dorsal sepal; $\mathbf{F}$ lateral sepal; G petal; H lip; J column, front view; K column, side view; L anther cap, dorsal view; M anther cap, ventral view. Based on spirit material Sieder 7112. DRAWN BY JUDI STONE. 
DISTRIBUTION. Endemic to Mahajanga province in northern Madagascar, only known from the type collection.

HABITAT. In semi-shade in riverine forest on rock. Elevation $900 \mathrm{~m}$.

CONSERVATION STATUS. Polystachya siederi is known from one location, outside a protected area in Sofia region, Mahajanga province. The habitat, the extent of occurrence and the area of occupancy face continuing decline due to fire and agricultural practices. Polystachya siederi is therefore assessed as Critically Endangered CR Blab(i,ii,iii) + 2ab(i,ii,iii).

FLOWERING TIME. January.

ETYMOLOGY. Named for Anton Sieder of the Botanical Garden, University of Vienna, Austria; an intrepid explorer, grower and connoisseur of the orchids of Madagascar.

NOTES. Polystachya is a pantropical genus of about 250 epiphytic, lithophytic or terrestrial plants, with the greatest diversity in sub-Saharan tropical Africa (Cribb in Pridgeon et al. 2014: 455). There are currently 23 Polystachya species recognised from the Madagascar, Mascarene and Comoro region, 16 of which are only found on Madagascar and three have a wider distribution outside the region.

\section{Acknowledgements}

We are most grateful to the directors and staff at BM, BR, BRLU, DBN, G, HEID, K, M, MO, P, SZU, TAN, TEF, W, WU, M, SZL, ZSS and their relevant libraries. We would like to thank the anonymous reviewers for their constructive suggestions and corrections, Judi Stone and Juliet Beentje for the detailed drawings and Michael Kiehn for his support. We are grateful to Heriniaina Thierra Augustin, one of the best guides at Ranomafana National Park who provided valuable field observations. We are also very grateful to Solo Rapanarivo, head of the flora department at PBZT Antananarivo, for his permission to use the collection at the PBZT herbarium and for providing the necessary collecting authorisation.

Open Access This article is licensed under a Creative Commons Attribution 4.0 International License, which permits use, sharing, adaptation, distribution and reproduction in any medium or format, as long as you give appropriate credit to the original author(s) and the source, provide a link to the Creative Commons licence, and indicate if changes were made. The images or other third party material in this article are included in the article's Creative Commons licence, unless indicated otherwise in a credit line to the material. If material is not included in the article's Creative Commons licence and your intended use is not permitted by statutory regulation or exceeds the permitted use, you will need to obtain permission directly from the copyright holder. To view a copy of this licence, visit http://creativecommons.org/ licenses/by/4.0/.

\section{References}

Bosser, J. (1965). Contribution à l'Étude des Orchidaceae de Madagascar V. Revision de quelques sections du genre Bulbophyllum à Madagascar. Adansonia 5: 375 - 410 .

(1969a). Contribution à l'Étude des Orchidaceae de Madagascar VIII. Adansonia 9: 293 - 298.

(1969b). Contribution à l'Étude des Orchidaceae de Madagascar IX. Adansonia 9: 299 - 309.

(1969c). Contribution à l'Étude des Orchidaceae de Madagascar X. Adansonia 9: 343 - 359.

(1969d). Contribution à l'Étude des Orchidaceae de Madagascar X. Adansonia 9: 539 - 547.

(1970a). Contribution à l'Étude des Orchidaceae de Madagascar XII. Adansonia 10: 95 - 110.

(1970b). Contribution à l'Étude des Orchidaceae

de Madagascar XIV. Adansonia 10: 367 - 373.

(1971). Contribution à l'Étude des Orchidaceae

de Madagascar XVI. Adansonia 11: 325 - 335.

(1980). Contribution à l'Étude des Orchidaceae de Madagascar. Adansonia 20: 257 - 261.

(1989). Contribution à l'Étude des Orchidaceae

de Madagascar XVIV. Adansonia 11: 29 - 38.

(2000). Contribution à l'Étude des Orchidaceae

de Madagascar et des Mascareignes. XXIX. Adansonia 22: 167 - 182.

(2006). Contribution à l'Étude des Orchidaceae de Madagascar et des Mascareignes. XXXV. Adansonia. 28: 53 - 61 .

(2007). Contribution à l'étude des Orchidaceae de Madagascar, des Comores et des Mascareignes. XXXVI. Adansonia 14: 13 - 17.

\& Lecoufle, M. (2011). Les Orchidées de Madagascar. Biotope, Mèze.

Callmander, M. W., Phillipson, P. B., Schatz, G. E., Andriambololonera, S., Rabarimanarivo, M., Rakotonirina, N., Raharimampionona, J., Chatelain, C., Gautier, L. \& Lowry, P. P. II. (2011). The endemic and non-endemic vascular flora of Madagascar updated. Pl. Ecol. Evol. 144: 121 - 125.

Cribb, P. J., Gautier, L., Trigui, S. \& Nusbaumer, L. (2011). Two new records of Orchidaceae from Madagascar, with an updated list of species shared with continental Africa. Candollea 66: 413 - 416.

\& Nusbaumer, L. (2013). How many species are there in the holomycotrophic genus Didymoplexis Griff. (Orchidaceae) in Madagascar? Candollea 68: 41 - 49.

\& Hermans, J. (2009). Field Guide to the Orchids of Madagascar. Kew Publishing, Royal Botanic Gardens, Kew. in Pridgeon, A. M., Cribb, P. J., Chase, M. W. \& Rasmussen, F. N. (2001). Genera Orchidacearum, Orchidoideae (Part 1) 2. Oxford University Press. 
in Pridgeon, A. M., Cribb, P. J., Chase, M. W. \& Rasmussen, F. N. (2014). Genera Orchidacearum, Epidendroideae (Part Three) 6. Oxford University Press.

\& Roberts, D. (2008). A new Habenaria from Madagascar. Orchid Rev. 116: 195 - 199.

Govaerts, R. (2019). World Checklist of Selected Plant Families. Facilitated by the Royal Botanic Gardens, Kew. Published on the Internet: http:// apps.kew.org/wcsp/.

Griffith, W. (1844). On some Plants, mostly undescribed, in the H. C. Botanic Gardens Calcutta. Calcutta J. Nat. Hist. 4: 375 - 390.

Hermans, J., Andriantiana, J. L., Sieder, A., Kiehn, M., Cribb, P., Rajavelona, L. \& Gardiner, L. (2017). New species and nomenclatural changes in Cynorkis (Orchidaceae: Orchidoideae) from Madagascar and the Mascarenes. Kew Bull. 72, 38: 1 - 31.

\& Cribb, P. (2014). New species and new names in Malagasy orchids (Orchidaceae). Kew Bull. 69: 9517, $1-16$.

, Hermans, C., Du Puy, D., Cribb, P. \& Bosser, J. (2007). Orchids of Madagascar $2^{\text {nd }}$ edition, Kew Publishing. Royal Botanic Gardens, Kew.

Hervouet, J.-M. (2018). A la recherche des Orchidées de Madagascar. Biotope, Mèze.

Hooker, J. D. (1891). Angraecum fastuosum, Bot. Mag. t.7202.

Hooker, W. J. (1824). Polystachya luteola. Exot. Fl. 2: t.103.

IUCN (2012). IUCN Red List Categories and Criteria. IUCN, Gland \& Cambridge.

Kraenzlin, F. (1900). Orchidaceae Africanae. Bot. Jahrb. Syst. 28: 162 - 179.

La Croix, I. (2014). Aerangis. Timber Press, Portland \& London.

Lindley, J. (1837). Notes upon some genera and species of Orchidaceae in the collection formed by Mr. Drége, at the Cape of Good Hope, Compan. Bot. Mag. 2: 200 - 210.

Martos, F., Johnson, S. \& Bytebier, B. (2015). Gastrodia madagascariensis (Gastrodieae, Orchidaceae): from an historical designation to a description of a new species from Madagascar. Phytotaxa 21: 048 - 056 , Pechon T. L., Johnson, S. D. \& Bytebier B. (2017). A reassessment of Angraecopsis, Mystacidium and Sphyrarhynchus (Orchidaceae: Vandeae) based on molecular and morphological evidence. Bot. J. Linn. Soc. 186: $1-17$.

Masters, M. T. (1885). Angraecum fastuosum, Gard. Chron. 23: 533.

Myers, N., Mittermeier, R. A., Mittermeier, C. G., da Fonseca, G. \& Kent, J. (2000). Biodiversity hotspots for conservation priorities. Nature 403: 853 - 858 .

Perrier de la Bâthie, H. (1930). Catalogue des Plantes de Madagascar. Orchidaceae d'après R. Schlechter. Colonie de Madagascar et Dépendances. Paris.
(1934). Le genre Benthamia (Orchidées). Bull. Soc. Bot. France 81: 25 - 38.

(1936a). Notes sur quelques Orchidées de Madagascar. Bull. Soc. Bot. France 83: 22 - 35.

(1936b). Notes sur quelques Habenaria en Madagascar. Bull. Soc. Bot. France 83: 579 - 585.

(1936c). Les Liparidinées de Madagascar. Notul. Syst. (Paris) 5: $231-260$.

(1937). Les Bulbophyllums de Madagascar. Notul. Syst. (Paris) 6: 41 - 124.

(1938a). Sarcanthae nouvelle ou peu connues de

Madagascar. Notul. Syst. (Paris) 7: $29-48$.

(1938b). Sarcanthae nouvelle ou peu connues de

Madagascar. Notul. Syst. (Paris) 7: 49 - 65.

(1938c). Sarcanthae nouvelle ou peu connues de

Madagascar (fin). Notul. Syst. (Paris) 7: 105 - 139.

(1938d). Bulbophyllum nouveau de Madagascar.

Notul. Syst. (Paris) 7: 139 - 143.

(1939a). Orchidées et Palmiers nouveau de Madagascar. Notul. Syst. (Paris) 8: 32 - 48.

(1939b - 1941). In: H. Humbert, Flore de

Madagascar. 49e. Famille. - Orchidées. (Vol. 1, 1939;

Vol. 2, 1941). Tananarive Imprimerie Officielle, Madagascar.

(1951). Orchidées de Madagascar et des Comores. Nouvelles observations. Notul. Syst. (Paris) 14: $138-165$.

in Humbert, H. (1955). Les Orchidées du Massif du Marojejy et de ses avant-monts, Mém. Inst. Sci. Madagascar, Sér. B, Biol. Vég. 6: 253 - 271.

Rasmussen, F. N. (1978). Observations on the genus Angraecopsis (Orchidaceae). Norweg. J. Bot. 25: 137 144.

Reichenbach, H. G. f. (1865). Dr. Welwitsch's Orchideen aus Angola. Flora 48: 177 - 191.

(1881a). VI Orchideae Hildebrandtianae. Otia Bot. Hamburg. 2 (1): $71-78$.

(1881b). Orchideae Hildebrandtianae. Bot. Zeitung (Berlin) 38: 447 - 450.

(1881c). New Garden Plants, Gard. Chron. 15: 748.

(1881d). New Garden Plants, Gard. Chron. 16: 844.

(1885a). Comoren-Orchideen Herrn Léon Humblot's. Flora 68: 377 - 382 .

(1885b). Comoren-Orchideen Herrn Leon Humblot's. Flora 68: 535 - 544 .

Ridley, H. N. (1883). Descriptions and Notes on new or rare Monocotyledonous plants from Madagascar, with one from Angola. J. Linn. Soc., Bot. 20: 329 - 338.

(1885). The Orchids of Madagascar. J. Linn. Soc., Bot. 21: 456 - 523 .

(1886). On Dr. Fox's collection of Orchids from Madagascar, along with some obtained by the Rev. R. Baron from the same Island.J. Linn. Soc., Bot. 22: 116-127. (1887). Catalogo da Flora da Ilha de S. Thomé. Bol. Soc. Brot. 5: $196-216$. 
Schlechter, R. (1895). Aufzählung der von mir auf meiner letzten Reise durch Natal und Transvaal gesammelten Orchideen. Beibl. Bot. Jahrb. Syst. 20: $20-44$.

(1913). Orchidacées de Madagascar. Orchidaceae Perrieranae Madagascarienses. Ann. Mus. Colon. Marseille, sér. 3. 148 - 202.

(1914). Die Orchideen: ihre Beschreibung, Kultur und Züchtung. Handbuch für Orchideenliebhaber, Züchter und Botaniker. P. Parey, Berlin.

(1915). Kritische Aufzählung der bisher von Madagaskar, den Maskarenen, Komoren und Seychellen bekanntgewordenen Orchidaceen. Beih. Bot. Centralbl. 33: 390 - 440.

(1916). Orchidaceae Perrierianae (Collectio secunda), Beih. Bot. Centralbl. 34: 1 - 341.

(1918a). Versuch einer natürlichen Neuordnung der afrikanischen angraekoiden Orchidaceen. Beih. Bot. Centralbl. 36: $62-181$.

(1918b). Additamenta ad Orchideologiam Madagascarensem. Repert. Spec. Nov. Regni Veg. Beih. 15: $324-340$.

(1920). Beschreibungen neuer Arten. Repert. Spec. Nov. Regni Veg. Beih. 7: 37 - 207.

(1922). Additamenta Orchideologiam Madagascarensem II. Repert. Spec. Nov. Regni Veg. Beih. 18: 320 - 326.

(1924). Orchidaceae Perrieranae. Repert. Spec. Nov. Regni Veg. Beih. 33: 1 - 240.

(1925). Orchidaceae Perrieranae. Repert. Spec. Nov. Regni Veg. Beih. 33: 241 - 391.
(1932). In: R. Mansfeld, Blütenanalysen neuer Orchideen, III. Afrikanische und Madagassische Orchideen, Repert. Spec. Nov. Regni Veg. Beih. 68: t.1 - 68 .

Stewart, J. (1986a). Stars of the Islands - A new look at the genus Aerangis in Madagascar and the Comoro Islands - 2. Amer. Orchid Soc. Bull. 55: $902-909$.

(1986b). Stars of the Islands - A new look at the genus Aerangis in Madagascar and the Comoro Islands - 4. Amer. Orchid Soc. Bull. 55: 1117 - 1125 .

\& Hennessy, E. F. (1980). Didymoplexis verrucosa - A new Saprophytic Orchid from South Africa. Amer. Orchid Soc. Bull. 49: 836 - 842.

Summerhayes, V. S. (1951). A revision of the genus Angraecopsis. Bot. Mus. Leafl. 14: 240 - 261.

(1951 publ. 1952). African Orchids XX. Kew Bull. 6: $461-475$.

(1953). African Orchids XXI. Kew Bull. 8: 129 - 162.

Thouars, A. du Petit. (1822). Histoire particulière des Plantes Orchidées recueillies sur les trois Îles Australes d'Afrique. Bertrand, Treuttel \& Wurtz, Paris.

Willdenow, C. L. (1805). Species Plantarum, ed. 4, 4. Berolini.

\section{Publisher's Note}

Springer Nature remains neutral with regard to jurisdictional claims in published maps and institutional affiliations. 